\title{
PENGARUH MODEL PEMBELAJARAN BERBASIS MASALAH BERBANTUAN MEDIA BONEKA TANGAN TERHADAP PENINGKATAN KETERAMPILAN BERBICARA SISWA KELAS VII-A MTS AL-HIKMAH CUPEL TAHUN PELAJARAN 2018/2019
}

\author{
Mas Heri Rusli, I Nyoman Sudiana, Sang Ayu Putu Sriasih. \\ Program Studi Pendidikan Bahasa Indonesia \\ Fakultas bahasa dan seni \\ Universitas pendidikan ganesha \\ Singaraja, Indonesia
}

e-mail: \{herirusli2207@gmail.com,sudiana19572@gmail.com, sap.sriasih@yahoo.com,

@undiksha.ac.id\}

\begin{abstract}
ABSTRAK
Penelitian ini bertujuan untuk mengetahui perbedaan keterampilan berbicara antara kelompok siswa yang belajar menggunakan model pembelajaran berbasis masalah berbantuan media boneka tangan dan kelompok siswa yang belajar menggunakan model pembelajaran konvensional pada siswa kelas VII di MTs Al Hikmah Cupel Tahun Pelajaran 2018/2019. Penelitian ini menggunakan quasi experiment dengan rancangan penelitian post-test only control group design. Populasi dalam penelitian ini adalah seluruh siswa kelas VII-A dan VII-B di MTs AI Hikmah Cupel, yang terdiri atas 30 orang siswa dimasing-masing kelas. Instrumen penelitian ini menggunakan keterampilan berbicara. Data yang diperoleh dianalisis dengan statistik deskriptif dan analisis statistik inferensial. Hasil penelitian menunjukkan, terdapat pengaruh keterampilan berbicara antara kelompok siswa yang belajar menggunakan model pembelajaran berbasis masalah berbantuan media boneka tangan lebih baik dalam hal kemampuan berbicara dibandingkan dengan model pembelajaran konvensional. Berdasarkan hal tersebut, dapat disimpulkan bahwa model pembelajaran berbasis masalah berbantuan media boneka tangan berpengaruh positif terhadap keterampilan berbicara siswa, saran dalam penelitian ini menjadikan salah satu aternatif untuk meningkatkan keterampilan berbicara.
\end{abstract}

Kata kunci: Model Pembelajaran Berbasis Masalah, Keterampilan Berbicara, Boneka Tangan

\begin{abstract}
This study aims to determine the differences in speaking skills between groups of students who learn using problem-based learning models assisted by hand puppet media and groups of students who learn to use conventional learning models in class VII students in MTs Al-Hikmah Cupel Academic Year 2018/2019. This study used quasi-experiment by making a post-test only control group design. The population in this study were all students of class VII-A and VII-B at MTs Al-Hikmah Cupel, which consisted of 30 students in each class. This research instrument uses speaking skills. The data obtained were analyzed by descriptive statistics and inferential statistical analysis. The results showed, there were influence in speaking skills between groups of students who learned to use a problem-based learning model assisted by hand puppet media better in terms of speaking ability compared to conventional learning models. Based on this, it can be concluded that the problembased learning model assisted by hand puppet media has a positive effect on students' speaking skills, the suggestions in this study make it an alternative for improving speaking skills
\end{abstract}


Keywords: Problem Based Learning Model, Speaking Skills, Hand Puppets

\section{PENDAHULUAN}

Pembelajaran adalah proses Kenyataan saat ini, dalam menjadikan anak agar mau belajar sesuai pembelajaran Bahasa Indonesia, dengan rencana yang telah ditetapkan. keterampilan berbicara siswa masih Belajar dapat diidentifikasi sebagai proses berpikir menekankan kepada proses mencari dan menemukan pengetahuan melalui interaksi antara individu dengan lingkungan, Sanjaya, (2009:107). Menjadikan anak mau belajar bukanlah hal yang mudah. Seorang guru dituntut untuk memotivasi siswa agar mau belajar dengan tekun. Mata pelajaran Bahasa Indonesia merupakan salah satu mata pelajaran yang ada di setiap jenjang sekolah. Hakikat belajar bahasa adalah belajar berkomunikasi.

Satata dkk. (2012:20), menyatakan bahwa komunikasi memiliki peranan penting dalam setiap interaksi sosial yang terjadi untuk menyampaikan perasaan, gagasan, dan pikiran kita kepada orang lain baik secara lisan maupun tulisan yang terjadi dalam satu arah maupun dua arah. Oleh karena itu, pembelajaran Bahasa Indonesia diarahkan untuk meningkatkan siswa agar mampu berkomunikasi dalam bahasa Indonesia, baik secara lisan maupun tertulis. kurang. Banyak dari siswa yang belum mampu menunjukkan keterampilan berbicaranya dengan baik. Anggapan bahwa setiap orang dengan sendirinya dapat berbicara telah menyebabkan pembinaan keterampilan berbicara sering diabaikan. Terkait dengan pernyataan tersebut, mutu pendidikan pada jenjang sekolah khususnya keterampilan berbicara sebagai sarana berkomunikasi masih menjadi persoalan ataupun masalah yang dialami siswa.

Pentingnya keterampilan berbicara bagi siswa dalam pembelajaran keterampilan berbicara perlu mendapat perhatian agar para siswa memiliki keterampilan berbicara, sehingga siswa mampu berkomunikasi untuk menyampaikan isi hatinya kepada orang lain dengan baik. Namun, keterampilan berbicara kurang diminati peserta didik karena tidak sedikit peserta didik yang masih malu atau kurang percaya diri dalam mengemukakan pendapatnya, siswa belum memiliki cukup keberanian, kurang percaya diri, dan tidak mampu 
menyampaikan gagasannya secara lancar dan sistematis, guru menggunakan pembelajaran konvensional, kurangnya inovasi pembelajaran.

Berdasarkan hasil observasi awal pada tanggal 08 November 2018 dengan siswa kelas VII di MTs Al-Hikmah Cupel, Kecamatan Negara, Kabupaten Jembrana, diperoleh informasi bahwa kemampuan berbicara siswa masih berada pada taraf cukup, gugup, dan kurang. Hal tersebut dapat dilihat selama proses pembelajaran berlangsung. Dalam proses pembelajaran, khususnya kegiatan berbicara, rata-rata dari kelas yang diobservasi, kebanyakan siswa merasa malu dan gugup ketika diminta bercerita. Selanjutnya, beberapa siswa lainnya seolah-olah tidak fokus dan sering menoleh ke segala arah seperti orang yang kebingungan ketika diminta untuk berbicara di depan kelas. Selain itu, masih terdapat banyak siswa yang tersendatsendat ketika berbicara.

Untuk itu, peneliti melakukan inovasi dalam proses pembelajaran menggunakan model dan media pembelajaran. Penggunaan model dan media pembelajaran juga sangat penting kehadiranya dalam proses pembelajaran. Minimnya penggunaan model dan media pembelajaran dari guru selama ini perlu dipecakan sedikit demi sedikit. Hal ini dimaksudkan agar siswa tidak hanya tinggi kualitas teori, tetapi juga tinggi kualitas praktik. Siswa hanya dijejali teori, pembelajaran yang konvensional ini tentu saja jarang dan bahkan tidak menggunakan media padahal pemanfaatan media memiliki peran penting terhadap pencapaian kualitas pembelajaran.

Banyak jenis media yang dapat digunakan dalam pembelajaran mendongeng salah satunya dengan media boneka tangan dapat menarik minat siswa. Boneka tangan tentunya sangat erat kaitannya dengan materi mendongeng, karena dengan menggunakan boneka tangan dalam proses pembelajaran di kelas tentunya siswa mengetahui karakter dari tokoh cerita, selain itu juga dapat menarik minat siswa dalam pembelajaran mendongeng. Tentunya dengan media boneka tangan dengan bantuan model pembelajaran berbasis masalah sangat menarik minat siswa pada pembelajaran, khususnya di Kurikulum 2013 yang lebih mengedapankan kreativitas siswa.

Penelitian ini didukung oleh penelitian sebelumnya yang telah dilakukan oleh Darmawan (2014) yang berjudul "pengaruh model pembelajaran role playing terhadap keterampilan berbicara bahasa Indonesia siswa kelas 
V". Penelitian yang dilakukan memperoleh kesimpulan berupa pembelajaran bahasa Indonesia menggunakan model pembelajaran role playing lebih efektif dibandingkan model pembelajaran konvensional. Hasil menunjukkan bahwa kelompok siswa yang mengikuti pembelajaran dengan model

pengaruh penerapan model pembelajaran berbasis masalah terhadap keterampilan berbicara siswa kelas VII-A MTs AlHikmah Cupel tahun pelajaran 2018/2019? 2. Sejauh mana pengaruh penerapan model pembelajaran berbasis masalah terhadap keterampilan berbicara siswa kelas VII-A MTs Al-Hikmah Cupel tahun pelajaran 2018/2019?

sesuai dengan rumusan masalah di atas, tujuan yang ingin dicapai dalampenelitian ini yaitu: 1. Untuk mengetahui pengaruh penerapan model pembelajaran berbasis masalah terhadap peningkatan keterampilan berbicara siswa kelas VII-A MTs Al-Hikmah Cupel tahun pelajaran 2018/2019. 2. Untuk mengetahui sejauh mana pengaruh penerapan model pembelajaran berbasisi masalah terhadap peningkatan keterampilan berbicara siswakelas VII-A MTs Al-Hikmah Cupel tahun pelajaran 2018/2019

\section{METODE PENELITIAN}

pembelajaran role playing memiliki keterampilan berbicara lebih baik dibandingkan dengan kelompok siswa yang mengikuti pembelajaran dengan media pembelajran konvesional.

Berdasarkan latar belakang tersebut, permasalahan yang diteliti dalam penelitian ini yaitu: 1. Apakah ada

Penelitian ini menggunakan rancangan eksperimen non-equivalent post-test only control group design. Setelah didapatnya satu kelompok kelas kontrol dan kelas eksperimen, maka kedua yang diberikan perlakuan secara berbeda. Pada kelas eksperimen pembelajaran dilakukan dengan menggunakan model pembelajaran berbasis masalah berbantuan media boneka tangan. Sedangkan kelas kontrol mengunakan model konvensional.

Desain penelitian yang digunakan dalam penelitian ini dapat dilihat pada tebel berikut.

\section{Tabel 1}

\section{Rancangan Peneletian Eksperimen}

\begin{tabular}{|l|l|l|}
\hline Kelas & Perlakuan & Post-test \\
\hline $\begin{array}{l}\text { Eksperimen } \\
(\mathrm{E})\end{array}$ & $\mathrm{X}$ & $\mathrm{O}_{1}$ \\
\hline Kontrol $(\mathrm{K})$ & - & $\mathrm{O}_{2}$ \\
\hline
\end{tabular}

Keterangan :

E : Kelompok eksperimen 
K : Kelompok kontrol

$X$ :Pelakuan berupa model pembelaran berbasis masalah berbantuan media boneka tangan terhadap peningkatan keterampilan berbicara.

- : perlakuan berupa pembelajaran model konvensional.

$\mathrm{O}_{1}$ dan $\mathrm{O}_{2}$ : post-test untuk kelas eksperimen dan kelas kontrol.

Dalam disain ini terdapat dua kelompok yang masing-masing dipilih secar rondom.

Menurut Sugiyono, (2008:117) Populasi adalah wilayah generalisasi yang terdiri atas objek dan subjek yang menjadi kuantitas dan karakteristik tertentu yang diterapkan oleh peneliti untuk dipelajari dan kemudian ditarik kesimpulannya Populasi adalah seluruh objek dalam suatu penelitian yang lengkap, jelas, dan mempunyai kualitas dan karakteristik tertentu yang ditetapkan untuk dipelajari kemudian ditarik simpulan. Populasi dalam penelitian ini adalah seluruh siswa kelas VII di MTs Al-Hikmah Cupel, yang terdiri atas 60 orang siswa.

Menurut Agung (2014:69), sampel adalah populasi yang diambil, yang dianggap mewakili seluruh populasi dan diambil dengan menggunakanteknik tertentu. Untuk menentukan sampel yang diteliti digunakan teknik sample random sampling. Random sampling dapat dilakukan karena ke dua kelas memiliki rata-rata hasil belajar yang setara. Berdasarkan hasil pengundian untuk menentukan kelas eksperimen dan kontrol, yaitu siswa kelas VII-A MTs AlHikmah Cupel sebagai kelas eksperimen dan siswa kelas VII-B MTs Al-Hikmah Cupel sebagai kelas kontrol. Kelas eksperimen diberikan perlakuan model pembelajaran berbasisi berbantuan media boneka tangan, kelas kontrol diberikan perlakuan dengan model pembelajaran konvensional.

Variabel Penelitian Menurut Agung (2014:40)variabel adalah suatu gejala berupa konsep yang akan menjadi titik fokus penelitian. Penelitian ini melibatkan variabel bebas dan variabel terikat yang dijelaskan sebagai berikut. 1. Variabel bebas (independent variable) variabel bebas dalam penelitian ini adalah media boneka tangan yang digunakan dalam kelompok eksperimen. 2. Variabel terikatdalam penelitian ini adalah peningkatan keterampilan berbicara. Prosedur penelitian dalam penelitian ini terdiri atas tiga tahapan, yaitu tahap persiapan, pelaksanaan, dan tahap akhir penelitian.

Data yang diperlukan dalam penelitian ini adalah data tes hasil keterampilan berbicara siswa. Metode yang digunakan untuk mengetahui hasil belajar siswa di kelas ekperimen dan 
kelas kontrol adalah metode tes keterampilan berbicara. Jenis tes yang digunakan dalam penelitian ini adalah observasi kuasi partisipasi. Data hasil tes keterampilan berbicara diperoleh dari nilai post-test siswa kelompok eksperimen setelah digunakannya motode berbasis masalah berbantuan media boneka tangan dalam pembelajaran mendongeng, dan nilai post-test kelompok kontrol tanpa menggunakan media serta menggunakan motode konvesional.

Analisis data yang digunakan dalam penelitian ini yaitu analisis statistik deskriptif digunakan untuk mengetahui

\begin{tabular}{|l|l|l|}
\hline Statistik & $\begin{array}{l}\text { Kelompok } \\
\text { Eksperimen }\end{array}$ & $\begin{array}{l}\text { Kelompok } \\
\text { Kontrol }\end{array}$ \\
\hline Mean & 79,63 & 67,97 \\
\hline Median & 80,17 & 68,83 \\
\hline Modus & 81,0 & 69,79 \\
\hline Standar Deviasi & 4,11 & 4,20 \\
\hline Varians & 16,93 & 17,62 \\
\hline
\end{tabular}

tinggi rendahnya kualitas dari dua variabel yaitu model pembelajaran berbasis masalah berbantuan media boneka tangan dan pembelajaran konvesional terhadap keterampilan berbicara yang mencakup mengitung nilai rata-rata, mean, modus, median, standar deviasi dan varians. Sedangkan teknik yang digunakan untuk menganalisis data guna pengujian hipotesis penelitian adalah uji-t sampel independent (tidak berkolerasi). Untuk bisa melakukan uji hipotesis, ada beberapa persyaratan yang harus dipenuhi dan perlu dibuktikan. Persyaratan yang dimaksud yaitu: 1. Data yang dianalisis harus berdistribusi normal dan 2. Data yang dianalisis harus bersifat homogen. Untuk membuktikan dan mememenuhi persyaratan tersebut, maka dilakukanlah uji prasyarat analisis dengan melakukan uji normalitas, dan uji homogenitas.

\section{HASIL PENELITIAN dan PEMBAHASAN}

$$
\text { Data yang disajikan dalam }
$$
penelitian ini adalah post-test keterampilan berbicara siswa yang terdiri atas dua kelompok yaitu (1) deskripsi post-test kelompok eksperimen deskripsi hasil post-test kelompok kontrol.

\section{Perbandingan Mean, Standar Deviasi dan Varians Keterampilan Berbicara Siswa pada Kelompok Eksperimen dan Kelompok Kontrol} Tabel 2

Berdasarkan Tabel 2 di atas, terlihat bahwa skor rata-rata (M) keterampilan berbicara siswa yang belajar dengan model pembelajaran berbasis masalah berbantuan media boneka tangan adalah 79,63 . Skor rata-rata (M) keterampilan berbicara siswa yang belajar dengan model pembelajaran konvensional adalah 67,97 . Hal ini menunjukkan bahwa keterampilan berbicara siswa yang belajar dengan model pembelajaran berbasis masalah berbantuan media boneka 
tangan lebih baik dibandingkan keterampilan berbicara siswa yang belajar dengan model pembelajaran konvensional.

Data hasil post-test kelompok eksperimen dapat disajikan ke dalam bentuk histogram dan poligon seperti Gambar 1 berikut ini.

poligon seperti Gambar 1 berikut ini.

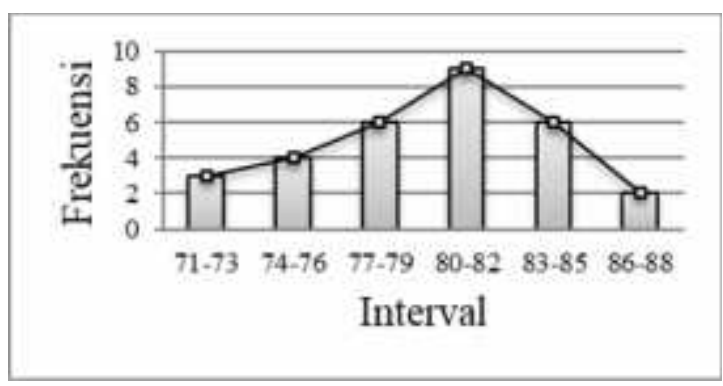

Gambar 1

Kurva Histogram dan Poligon Data Hasil

post-test Kelompok Eksperimen

Untuk mengetahui kualitas dan klasifikasi dari variabel hasil post-test keterampilan berbicara pada siswa yang belajar dengan model pembelajaran berbasis masalah berbantuan media boneka tangan, maka skor rata-rata dikonversikan dengan menggunakan kriteria rata-rata ideal $(\mathrm{Mi})$ dan standar deviasi ideal (SDi), diperoleh bahwa skor rata-rata tes keterampilan berbicara siswa kelompok eksperimen tergolong tinggi.

Data hasil post-test kelompok kontrol dapat disajikan ke dalam bentuk histogram dan poligon seperti Gambar 2 berikut ini.

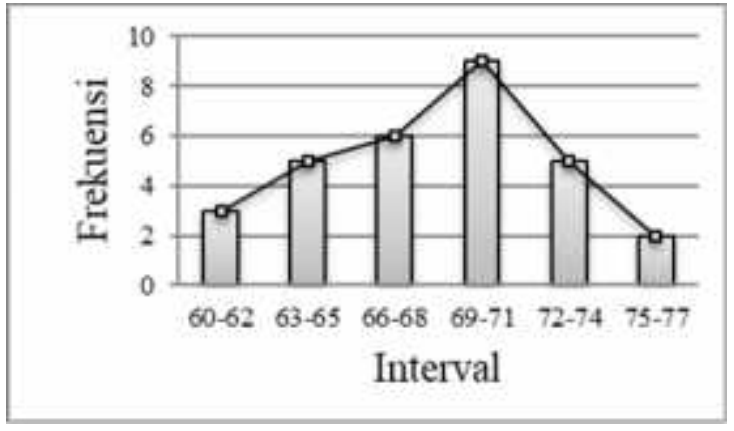

Gambar 2

Kurva Histogram dan Poligon Data Hasilpost-test Kelompok Kontrol

Untuk mengetahui kualitas dan klasifikasi dari variabel hasil post-test keterampilan berbicara pada siswa yang belajar dengan model pembelajaran konvensional, maka skor rata-rata dikonversikan dengan menggunakan kriteria rata-rata ideal (Mi) dan standar deviasi ideal (SDi). Diperoleh bahwa skor rata-rata tes keterampilan berbicara siswa kelompok kontrol tergolong cukup.

Uji normalitas sebaran data dan uji homogenitas dilakukan sebelum uji hipotesis. Uji normalitas sebaran data dilakukan untuk membuktikan bahwa frekuensi data hasil penelitian berdistribusi normal. Hasil analisis data post-test kelas eksperimen dengan menggunakan rumus Chi-Square diperoleh hasil post-test kelompok eksperimen adalah 2,265 dan pada taraf signifikansi $5 \%$ dengan $\mathrm{dk}=5$ adalah 11,070. Berarti, hasil post-test kelompok eksperimen lebih kecil dari (< 
). Hal ini menunjukkan bahwa sebaran data keterampilan berbicara siswa pada kelompok eksperimen berdistribusi normal. Menunjukkan bahwa hasil perhitungan dapat dipaparkan dengan menggunakan rumus Chi-Square diperoleh, hasil post-test kelompok kontrol adalah 1,124 dan pada taraf signifikansi $5 \%$ dengan $\mathrm{dk}=5$ adalah 11,070 . Berarti, hasil post-test kelompok kontrol lebih kecil dari $(<)$. Hal ini menunjukkan bahwa sebaran data keterampilan berbicara siswa pada kelompok kontrol berdistribusi normal.

Hasil uji homogenitas varians untuk kelompok model pembelajaran berbasis masalah berbantuan media boneka tangan dengan model pembelajaran konvensional menunjukkan Fhitung hasil post-test kelompok eksperimen dan kontrol adalah 1,041, sedangkan $F$ tabel dengan taraf signifikansi $5 \%$ dan dkpembilang $=1$, dkpenyebut $=57$ adalah 4,01. Hal ini menunjukkan bahwa $F$ hitung lebih kecil dari Ftabel ( $F$ hitung $<F$ tabel) sehingga $\mathrm{HO}$ diterima. Hal ini berarti bahwa variansi pada setiap kelompok adalah sama (homogen).

Berdasarkan uji normalitas sebaran data dan uji homogenitas varians diperoleh hasil bahwa keterampilan berbicara siswa pada kelompok eksperimen dan kelompok kontrol berdistribusi normal dan bersifat homogen. Berdasarkan hal tersebut, maka pengujian hipotesis penelitian dapat dilanjutkan. Hipotesis penelitian yang telah dikemukakan dalam kajian teori menyatakan bahwa terdapat pengaruh yang signifikan terhadap keterampilan berbicara siswa yang belajar dengan model pembelajaran berbasis masalah berbantuan media boneka tangan dengan siswa yang belajar dengan model pembelajaran konvensional. Pengujian hipotesis menggunakan uji-t sampel independent (tidak berkorelasi). Karena $\mathrm{n} 1 \neq \mathrm{n} 2$ dan varians homogen, maka rumus uji-t yang digunakan adalah uji-t polled varians. Hipotesis statistik yang diuji dalam pengujian hipotesis adalah sebagai berikut.

$\mathrm{H}_{0}$ : tidak terdapat pengaruh yang signifikan terhadap keterampilan berbicara siswa yang diberikan perlakuan model pembelajaran berbasis masalah berbantuan media boneka tangan dan siswa yang diberikan perlakuan model pembelajaran konvensional kelas VII MTs Al-Hikmah Cupel tahun pelajaran 2018/2019.

$\mathrm{H}_{\mathrm{a}}$ : terdapat pengaruh yang signifikan terhadap keterampilan berbicara siswa yang diberikan perlakuan model pembelajaran berbasis masalah berbantuan media boneka tangan dan 
siswa yang diberikan perlakuan model pembelajaran konvensional kelas VII MTs Al-Hikmah Cupel tahun pelajaran 2018/2019.

Kriteria pengujiannya adalah jika $t_{\text {hitung }}>t_{\text {tabel }}$, maka $\mathrm{H}_{0}$ ditolak, sedangkan jika $t_{\text {hitung }}<t_{\text {tabel}}$, maka $\mathrm{H}_{0}$ diterima. Hasil analisis dengan uji-t polled varians tampak pada Tabel 1.2 berikut ini.

Data hasil post-test kelompok eksperimen dapat disajikan ke dalam bentuk histogram dan

Tabel 3

Hasil Uji-t

Berdasarkan Tabel 3 di atas, diperoleh $t_{\text {hitung }}$ sebesar 10,871, sedangkan $t_{\text {tabel }}$ dengan taraf signifikansi $5 \%$ dan $\mathrm{dk}=30+30-2=58$ adalah 2,002. Hal ini menunjukkan bahwa $t_{\text {hitung }}$ lebih besar dari $t_{\text {tabel }}$ ( $t_{\text {hitung }}>t_{\text {tabel }}$ ), sehingga $\mathrm{H}_{0}$ ditolak. Hal ini menunjukkan bahwa terdapat pengaruh yang signifikan terhadap keterampilan berbicara siswa yang diberikan perlakuan model pembelajaran berbasis masalah berbantuan media boneka tangan dan siswa yang diberikan perlakuan model pembelajaran konvensional kelas VII MTs Al-Hikmah Cupel tahun pelajaran 2018/2019.

\section{PEMBAHASAN}

Proses pembelajaran yang berlangsung di MTs Al-Hikmah Cupel, khususnya pada siswa kelas VII menggunakan dua model pembelajaran, yaitu model pembelajaran berbasis masalah pada kelas eksperimen dan pembelajaran konvensional pada kelas kontrol. Proses belajar berbicara pada kelompok eksperimen diberikan sebuah perlakuan dengan menggunakan model pembelajaran berbasis masalah berbantuan media boneka tangan. Penggunaan model pembelajaran ini guna manarik perhatian dan minat belajar siswa dalam mengikuti pembelajaran

\begin{tabular}{|c|c|c|c|c|c|c|c|}
\hline Data & $\begin{array}{l}\text { Kelomp } \\
\text { ok }\end{array}$ & $\mathrm{N}$ & $\bar{X}$ & $s^{2}$ & $\begin{array}{l}\mathrm{t}_{\text {hitun }} \\
\mathrm{g}\end{array}$ & $\begin{array}{l}\mathrm{D} \\
\mathrm{k}\end{array}$ & $\begin{array}{l}\mathrm{t}_{\text {tabel }} \\
(5 \%)\end{array}$ \\
\hline \multirow{2}{*}{$\begin{array}{l}\text { Ketera } \\
\text { mpilan } \\
\text { Berbic } \\
\text { ara }\end{array}$} & $\begin{array}{l}\text { Eksperi } \\
\text { men }\end{array}$ & $\begin{array}{l}3 \\
0\end{array}$ & $\begin{array}{l}79 \\
63\end{array}$ & $\begin{array}{l}16, \\
93\end{array}$ & \multirow{2}{*}{0,871} & \multirow{2}{*}{$\begin{array}{l}5 \\
8\end{array}$} & \multirow{2}{*}{2,002} \\
\hline & Kontrol & $\begin{array}{l}3 \\
0\end{array}$ & $\begin{array}{l}67, \\
97\end{array}$ & $\begin{array}{l}17, \\
62\end{array}$ & & & \\
\hline
\end{tabular}

mendongeng dengan bantuan media boneka tangan di dalam kelas.

Secara deskriptif, hasil tes keterampilan berbicara siswa pada kelompok siswa yang belajar dengan model pembelajaran berbasis masalah berbantuan media boneka tangan memiliki hasil yang lebih tinggi dibandingkan dengan kelompok siswa yang mengikuti pembelajaran dengan pembelajaran konvensional. Hal ini didasarkan pada rata-rata skor hasil tes keterampilan berbicara siswa. Rata-rata skor hasil tes keterampilan berbicara siswa dengan 
model pembelajaran berbasis masalah berbantuan media boneka tangan adalah 79,63. dan rata-rata skor belajar hasil tes keterampilan berbicara yang mengikuti pembelajaran dengan pembelajaran konvensional adalah 67,97.

Berdasarkan analisis inferensial yang menggunakan uji-t, diperoleh thitung sebesar 10,871, sedangkan ttabel dengan taraf signifikansi $5 \%$ dan $\mathrm{dk}=30+30-2$ $=58$ adalah 2,002. Hal ini berarti bahwa thitung lebih besar dari ttabel (thitung > ttabel), sehingga HO ditolak. Dapat dilihat dari $\mathrm{t}$ hitung $>\mathrm{t}$ tabel sebesar 10,871>2,002 yang menunjukkan bahwa terdapat pengaruh yang signifikan antara keterampilan berbicara siswa yang diberikan perlakuan model pembelajaran berbasis masalah berbantuan media boneka tangan dan siswa yang diberikan perlakuan model pembelajaran konvensional kelas VII MTs Al-Hikmah Cupel tahun pelajaran 2018/2019.

Hasil analisis tersebut membuktikan bahwa adanya pengaruh hasil tes keterampilan berbicara secara signifikan antara siswa yang belajar dengan model pembelajaran berbasis masalah berbantuan media boneka tangan dan siswa yang belajar dengan pembelajaran konvensional. Hal tersebut terjadi karena model pembelajaran berbasis masalah berbantuan media boneka tangan dalam penerapannya di kelas memberikan dampak yang baik terhadap keterampilan berbicara siswa dan juga siswa terlihat antusias mengikuti pembelajaran karena pembelajaran berlangsung menyenangkan dan tidak menoton. Penerapan model pembelajaran berbasis masalah berbantuan media boneka tangan menimbulkan konsekuensi logis yaitu, siswa lebih tertantang dalam meningkatkan kemampuan dalam berbicara karena siswa berlatih secara langsung di depan seluruh teman-teman dengan tuntutan lafal, ekspresi, dan lancar dioalog yang baik dan benar.

Adapun temuan di lapangan yang merupakan dampak positif dari penerapan media pembelajaran adalah siswa termotivasi dalam kegiatan pembelajaran mendongeng, secara tidak langsung siswa lebih berani untuk berbicara ketika diminta berbicara dan siswa sangat antusias ingin menceritakan cerita dongeng dengan bantuan media di depan teman-temannya. Pernyataan di atas didukung oleh Hamalik dalam Arsyad, (2006:9), menyatakan bahwa manfaat media pembelajaran dalam proses belajar-mengajar akan membangkitkan motivasi dan rangsangan kegiatan belajar.

Jika dilihat dari filosofisnya, model pembelajaran berbasis masalah dapat mengubah pembelajaran yang awalnya berpusat pada guru menjadi pembelajaran yang berpusat pada siswa. Hal ini 
disebabkan oleh kegiatan pembelajaran yang mengacu pada sinteks model pembelajaran berbasis masalah. Selama proses pembelajaran guru berperan sebagai fasilitator dan mediator, sementara siswa aktif dalam memecahkan masalah yang diberikan guru khususnya dalam kompetensi dasar, memerankan isi fabel/legenda daerah setempat yang dibaca atau didengar. Pernyataan di atas sejalan dengan pendapat Sanjaya (2016:217), model pembelajaran berbasis masalah adalah model yang berawal dari masalah yang diberikan kepada siswa dan dipecahkan oleh siswa dengan bimbingan guru. Model pembelajaran ini tentunya lebih menarik minat siswa jika dapat dipadukan dengan media pembelajaran.

$$
\text { Penyampaian matari dalam }
$$
pembelajaran berbasis masalah disajikan dalam bentuk mendongeng yang diperankan oleh siswa. Selama proses pembelajaran, siswa memerankan tokoh dongeng yang terdapat dalam cerita dengan menggunakan media boneka tangan secara langusng di hadapan teman-temanya, sehingga siswa bisa melatih berbicara dengan aktif dan bermakna. Selain itu penggunaan media boneka tangan dalam mendongeng membuat pembelajaran terasa menyenagkan dan menarik minat siswa. Bahkan beberapa kali ingin mengulangi menceritkan dongeng menggunakan boneka tangan. Sejalan dengan pendapat Cecep (2011:35), boneka tangan adalah sebuah sarung tangan dengan karakterkarakter yang berbeda di setiap jarinya. Bisa juga berupa binatang atau wajah karakter kartun, boneka tangan sebagai alat yang bagus untuk menarik perhatian siswa yang berguna dalam meningkatkan kemampuan berbahasa dan berbicara. Dalam hal ini media boneka tangan berguna untuk menimbulkan gairah dan keatifan siswa dalam belajar berbicara.

Berdasarkan uraian di atas, terlihat bahwa model pembelajaran berbasis masalah berbantuan media boneka tangan lebih unggul dibandingkan dengan pembelajaran konvensional. Hal ini menunjukkan bahwa terdapat pengaruh perbedaan yang signifikan terhadap keterampilan berbicara siswa yang diberikan perlakuan model pembelajaran berbasis masalah berbantuan media boneka tangan dan siswa yang diberikan perlakuan model pembelajaran konvensional kelas VII MTs Al-Hikmah Cupel tahun pelajaran 2018/2019. Hasil belajar siswa yang singnifikan dapat dilhat dari rata-rata nilai kelas eksperimen lebih tinggi dari pada kelas kontrol sebesar 79,63 (katagori tinggi) > 67,97 (katagori cukup) sehingga menunjukkan ada pengaruh positif model pembelajaran berbasis masalah berbantuan media 
boneka tangan terhadap siswa kelas VII MTs Al-Hikmah Cupel tahun pelajaran 2018/2019.

Jadi, pembelajaran yang menggunakan model pembelajaran berbasis masalah berbantuan media boneka tangan berpengaruh positif dalam meningkatkan keterampilan berbicara siswa daripada pembelajaran konvensional, siswa kelas VII MTs Al Hikmah Cupel tahun pelajaran 2018/2019. Pengaruh positif yang ditimbulkan dalam penelitian tersebut adalah siswa lebih berani dan percaya diri berbicara ketika diminta berbicara di depan kelas. Selain itu, siswa merasa lebih senang dan aktif dalam mengikuti pembelajaran berbasis masalah sehingga keterampilan berbicara siswa dapat meningkat.

\section{SIMPULAN DAN SARAN}

Berdasarkan hasil penelitian dan pembahasan, dapat disimpulkan bahwa terdapat pengaruh penggunaan model pembelajaran berbasis masalah berbantuan media boneka tangan terhadap peningkatan keterampilan berbicara siswa kelas VII MTs Al-Hikmah Cupel tahun pelajaran 2018/2019. Hal ini menunjukkan bahwa terdapat pengaruh yang signifikan antara keterampilan berbicara siswa yang diberikan perlakuan model pembelajaran berbasis masalah berbantuan media boneka tangan dan siswa yang diberikan perlakuan model pembelajaran konvensional kelas VII MTs Al-Hikmah Cupel tahun pelajaran 2018/2019. Rata-rata skor hasil tes keterampilan berbicara siswa dengan model pembelajaran berbasis masalah berbantuan media boneka tangan adalah 79,63. Termasuk dalam katagori tinggi dan rata-rata skor belajar hasil tes keterampilan berbicara yang mengikuti pembelajaran dengan pembelajaran konvensional adalah 67,97. Termasuk dalam katagori cukup. Dengan demikian, model pembelajaran berbasis masalah berbantuan media boneka tangan berpengaruh positif terhadap keterampilan berbicara siswa.

Saran yang dapat disampaikan berdasarkan penelitian yang telah dilakukan adalah disarankan bagi guru bahasa Indonesia di MTs Al-Hikmah Cupel, hasil penelitian ini dapat digunakan sebagai pedoman dalam memilih dan menggunakan media pembelajaran berbasis masalah berbantuan media boneka tangan, salah satu aternatif untuk meningkatkan keterampilan berbicara siswa. Saran selanjutnya ditujukan bagi Kepala Sekolah di MTs AI-Hikmah Cupel, hasil penelitian ini dapat digunakan sebagai salah satu pedoman dan menyusun kebijakan pengadaan pelatihan merancang media pembelajaran bagi guru-guru bahasa Indonesia. Selanjutnya 
saran bagi peneliti lain, disarankan melakukan penelitian lebih lanjut dengan subjek yang lebih banyak tentang pengaruh model pembelajaran berbasis masalah berbantuan media boneka tangan terhadap pengingkatan hasil berbicara siswa. Hasil penelitian ini dapat dijadikan bahan pertimbangan untuk perbaikan dan penyempurnaan penelitian selanjutnya.

\section{DAFTAR RUJUKAN}

Agung, Anak Agung Gede. (2014). Metodologi Penelitian Pendidikan.Singaraja: Fakultas Ilmu Pendidikan Universitas Pendidikan Ganesha.

Arsyad, Azhari. 2014. Media Pembelajaran. Jakarta: Rajarwali Pers.

Kustandi, Cecep. 2011. Media Pembelajaran Manual dan Digital. Bogor: Ghalia Indonesia.

Sanjaya, (2009). Starategi Pembelajaran Berorentasi Standar Proses Pendidikan. Prenada: Jakarta.

Satata, Sri dan Devi Suswandari dkk. 2012. Bahasa Indonesia Mata Kuliah
Pengembangan Kepribadian. Jakarta: Mitra Wacana Media.

Sugiyono. (2008). Metode Penelitian Pendidikan Pendekatan Kuantitatif, Kualitatif dan $R \& D$. Bandung: Alfabeta. 